\title{
表情は模倣されるのか
}

日本人参加者を用いた検討

\author{
田村亮 1.2 龟田達也 北海道大学
}

\section{Are facial expressions contagious in the Japanese?}

\author{
Ryo Tamura and Tatsuya Kameda (Hokkaido University)
}

\begin{abstract}
Previous studies, mainly with Caucasian samples, have shown that facial expressions of emotion are contagious, a phenomenon known as facial mimicry. This study examined facial mimicry using a Japanese sample. Participants were shown a series of Japanese faces (from Matsumoto and Ekman, 1988) on a computer screen expressing "happiness", "sadness", "anger", or "disgust." While viewing the facial expressions, electoromyograms (EMG) of the participants' faces were recorded to see whether their own facial muscles corresponding to the stimulus faces were activated. Consistent with the previous studies using Caucasian samples, all four facial expressions were mimicked. The peak time of mimicry of angry or happy faces was later, while that of disgusted faces was relatively sooner. The potential relation of facial mimicry to "emotional contagion", a social phenomenon whereby subjective feelings transfer between people, is discussed.
\end{abstract}

Key words: facial mimicry, affect, electoromyogram (EMG), ẹmotional contagion.

The Japanese Journal of Psychology

2006, Vol. 77, No. 4, pp. 377-382

近年，共感の一側面として，表情模倣（facial mimicry）が注目されている。表情模倣とは，心的状態と 概念的に独立に，個体間で同一の顔面筋が活性化して いる状態を指す。Blairy, Herrera, \& Hess（1999）は, この表情模倣の機能として, 他者の感情状態の把握を あげ，他者の表情を自ら再現することが，他者感情の 理解の助けになると主張する。また Hess \& Blairy （2001）は，個体間で感情的心理状態が同期化する情 動伝染（emotional contagion; Hatfield, Cacioppo, \& Rapson, 1994）と呼ばれる現象と, 表情模倣の関係に 注目し，他者との感情共有が表情模倣を通じて行われ ているのではないかと議論している。

同様の問題意識から, Dimberg らも顔面筋電図

Correspondence concerning this article should be sent to: Ryo Tamura. Department of Behavioral Science. Graduate School of Letters. Hokkaido University, Kita-ku, Sapporo 060-0810. Japan (e-mail: tamura (alynx.let.hokudai.ac.jp)

実験参加希望者の募集に際して, 浅見克彦, 安達真由美, 荒井正彦, 池田隆司, 石原孝二, 井上久遠, 煎本孝, 上田宏, 宇都宮輝夫, 太田敬子, 大塚吉則, 菊地武, 櫻井義秀, 志堅原 郁子, 下澤楯夫, 鈴木誠, 関孝敏, 瀬名波栄潤, 祖田亮次, 高 田泰弘, 高橋伸幸, 中林孝和, 橋本雄一, 宮武公夫, 室橋春光, 望月恒子, 森田学, 森谷絜, 山崎孝治, 山村悦夫, 結城雅樹, 㢩和順, 亘理格, 和田宏の諸先生方にご協力いただきました。

ここに記して感謝いたします。

日本学術振興会特別研究員。 (facial electoromyogram : 以下 facial EMG とする) を用いた一連の実験を行い，表情模倣の証拠を示して いる (Dimberg, 1982; Lundqvist \& Dimberg, 1995)。 彼らはまた，表情刺激が閾下呈示される場合にも模倣 が生じることを明らかにし，表情模倣が自動的なプロ セスである可能性を示している（Dimberg \& Thunberg, 1998; Dimberg, Thunberg, \& Elmehed, 2000)。

以上の上うに，表情模倣に関する検討は，主に北米 及びヨーロッパを中心として行われているが，この現 象について日本人サンプルを用いた実証的な検討はほ とんど存在しない。わずかに，市川・牧野（2004）が 印象評定法を用いた先駆的検討を行っているのみであ る。印象評定法では，表情刺激を見ている実験参加者 の表情を，他の観察者に評定させるという方法をとる (Gump \& Kulik, 1997; Hinsz \& Tomhave, 1991)。し かしこの方法は，観察者の評定に依拠するため客観性 に欠けるという問題をもち，市川・牧野（2004）の知 見も表情模倣の十分に明確な証拠を示していない。

表情模倣という行動特性が，人がもつ基本的性質で あるかを確認することは，“共感”や“情動伝染”の 生起メカニズムを明らかにする上で, 非常に重要な基 礎的デー夕を提供する。本研究では, 表情の微細な変 化の客観的測定が可能な顔面筋電図（facial EMG） 
Table 1

主観的感情を測定するために用いられた評定語

\begin{tabular}{|c|c|c|c|}
\hline 怒り感情 & 頭にきた & いらいらした & 怒った \\
\hline 嫌悪感情 & 受け入れがたい & むかむかした & うんざりした \\
\hline 喜び感情 & 楽しい & あたたかい & 高揚した \\
\hline 悲しみ感情 & 悲しい & 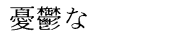 & がっかりした \\
\hline
\end{tabular}

を用いて，日本人サンプルにおける表情模倣の可能性 を検討する。同時に本研究では，行動的反応である表 情模倣と，心理的反応である情動伝染との関係を，探 索的に検討する。

予測 本研究ではHess \& Blairy（2001）に倣い, “怒り”，“嫌悪”，“喜び”，“悲しみ”の 4 表情の模倣 に関して，実証的検討を行う。表情が模倣されるので あれば，“嫌悪”表情刺激に対しては，鼻の上にしわ を寄せる働きをもつ上唇鼻翼挙筋が，また“喜び”表 情刺激に対しては，目尻を下げる眼輪筋と口角を引き 上げる大煩骨筋が，それぞれ活性化すると予測され る。一方, “怒り”及び“悲しみ”表情は, 眉根に位 置する皺眉筋の活動により表出されるため, これらの 表情刺激に対しては，皺眉筋の活性化が予測される。 なお，“怒り”表情では口輪筋が，また“悲しみ”表 情では口角下制筋が，それぞれ皺眉筋以外にも活性化 するが, 使用する実験装置のチャンネル数の制約か ら，本研究では皺眉筋に注目した。

\section{方 法}

実験参加者 4 年制大学の 1 年生 40 名（男性 22 名, 女性 18 名)。

刺激 本実験では, Hess \& Blairy（2001）に倣い, “怒り”, “嫌悪”, “喜び”, “悲しみ”の 4 表情を, 男 女 2 名ずつ写真により呈示した。刺激写真は,

Matsumoto \& Ekman（1988）により作成された表情 刺激のうち, アメリカ在住の日本人, 及び日系アメリ カ人の写真を使用した。これらの刺激写真では, 表情 ごとに表出者が異なっているが，各表情につき 4 人物 の写真を用いることで，特定の人物写真による効果を 減少させた。

装置 Biopac 社製 MP150 システムをアンプとして 用い, Hess \& Blairy (2001) と同様, 上唇鼻翼挙筋, 大煩骨筋，眼輪筋，皺眉筋の各筋電位を測定した。電 極は Biopac 社製銀塩化銀血電極 EL254S（直径 7.2 mm）を使用し， Fridlund \& Cacioppo（1986）による ガイドラインに従って，装着部位を決定した。EMG データは $1 \mathrm{kHz}$ のサンプリングレートで抽出され, EMG 波形は全波整流後に積分演算された。また，外 部からのノイズ除去のため，ハイパスフィル夕とロー パスフィルタをそれぞれ $10 \mathrm{~Hz}$ と $500 \mathrm{~Hz}$ に設定した。

手続き 本実験では, 全 16 試行が行われた。各試
行では，まずニュートラル表情の人物写真が，15 秒 間コンピュータ画面上に呈示され，その後 5 秒のイン ターバルを挟み, 同一人物の感情表情が，15 秒間呈 示された（Hess \& Blairy, 2001）。さらに，感情表情刺 激がモニターから消えた後, 参加者は, その時点での 主観的な感情状態を回答するよう指示された。

この質問では，“怒り”，“嫌悪”，“喜び”，“悲しみ” の 4 タイプの主観的感情を測定するため，それぞれに つき 3 種類の評定語を用いた。評定語の種類は Table 1 に示すとおりであり,これらはCacioppo, Martzke, Petty, \& Tassinary（1988）で使用された単語から選択 した。参加者は各表情に対する 4 種類の感情を, モ二 ター上のレバーを，0（まったくそうでない）-100 (強くそうである) の間で移動させることで回答した。 評定レバーは，各試行の評定が終了するごとに，中点 に戻るよう設定された。

参加者の筋反応は，実験全期間を通して前述の 4 部 位において常に測定された。また，刺激呈示順序の力 ウンターバランスをとるため, 正順と逆順の 2 通りを 設定した。

\section{結 果}

数量化 感情表情刺激に対する筋反応とニュートラ ル表情刺激に対する筋反応の差分を刺激誘発成分と し，その值を，感情表情刺激の種類別に算出した。ま た，主観的感情報告についても同様に，感情表情刺激 の種類別に，回答值を算出した。なお，筋反応データ (EMG) については，分布に正規性が認められなかっ たため，開平変換を行った。

刺激呈示全期間（15 秒間）のデータを用いた分析 本研究では，様々な感情表情を知覚した際，参加者が 刺激写真と同様の表情を表出すると予測している。こ こではまず，刺激呈示全期間（15秒間）を，分析対 象区間とした検討を行う。Figure 1 は，刺激誘発成 分（感情表情刺激に対する筋反応とニュートラル表情 刺激に対する筋反応の差分）の平均值を示している。 表情が模倣されるのであれば，刺激写真で活性化して いる顔面筋と同一の筋における刺激誘発成分の值が, 高まるはずである。

感情表情の種類別に，刺激誘発成分值が 0 と有意に 異なるかどうかの $t$ 検定を行った結果，“嫌悪”表情 を呈示した場合には，特に上唇鼻翼挙筋の活性化は確 
認されなかった $(t(39)=1.08, n s)$ 。一方で, “怒り” 表情を呈示した場合, 哗眉筋が活性化し $(t(39)=$ $1.98, p<.05)$, “悲しみ” 表情を呈示した際も, 同様 に皺眉筋の活性化が見られた $(t(39)=3.74, p<$ .01)。また, “喜び” 表情を呈示した場合に, 大煩骨 筋 $(t(39)=2.51, p<.05)$ と眼輪筋 $(t(39)=2.43$, $p<.05 ）$ が活性化することも，同時に示された。

“嫌悪” 表情を除き, これらの顔面筋の活性化は, 先行研究の結果と一貫するものだが, 先行研究からは 予測されなかった反応も確認された。例えば，“怒り” 表情に対して, 皺眉筋以外にも, 大煩骨筋 $(t(39)=$ $3.32, p<.01)$ と眼輪筋 $(t(39)=3.82, p<.01)$ が活 性化している。また, “嫌悪” 表情に対しては大煩骨 筋 $(t(39)=1.96, p<.05)$ が，“喜び”表情に対して は上唇鼻翼挙筋 $(t(39)=2.37, p<.05)$ が，それぞれ 反応している。

刺激呈示直後 1 秒間のデータを用いた分析 上記の 分析では, 刺激呈示後 15 秒間という, かなり長い時 間のデータを用いたが, 表情模倣は, 刺激の呈示が閾 下で行われる場合にもごく短時間のうちに生起するこ とが報告されている（Dimberg \& Thunberg，1998;
Dimberg et al., 2000)。すなわち, 表情刺激の種類に よっては, 刺激呈示直後に模倣が生起した可能性があ る。そこで, 刺激呈示直後 1 秒間のデー夕を使用し, 改めて表情模倣が生じていたかの検討を行った。

Figure 2 は, 刺激呈示直後 1 秒間の刺激誘発成分 值（感情表情刺激に対する筋反応とニュートラル表情 刺激に対する筋反応の差分）の平均を示している。こ のデータを用いて再び $t$ 検定を行ったところ, “嫌悪” 表情に対する上唇鼻翼挙筋の活性化が見られ $(t(37)=1.68, p<.05)$, 刺激呈示全期間（15秒間） のデータでは確認されなかった “嫌悪”表情の模倣が 確認された。

また, 予測と一貫して, “悲しみ” 表情に対する㱀 眉筋の活性化が確認された $(t(37)=1.65, p=.05)$ 。 一方, “怒り”表情に対する㱀眉筋 $(t(37)=1.48$, $n s)$, 及び “喜び” 表情に対する大煩骨筋 $(t(39)=$ $-1.38, n s)$ と眼輪筋 $(t(39)=0.89, n s)$ の活性化 は, 刺激呈示全期間 (15 秒間) とは異なり, 刺激呈 示直後 1 秒間の $\mathrm{EMG}$ データでは認められなかった。

以上, 顔面筋電図のデータから得られた知見は, 表 情模倣反応がピークに達する時間が, 感情表情の種類

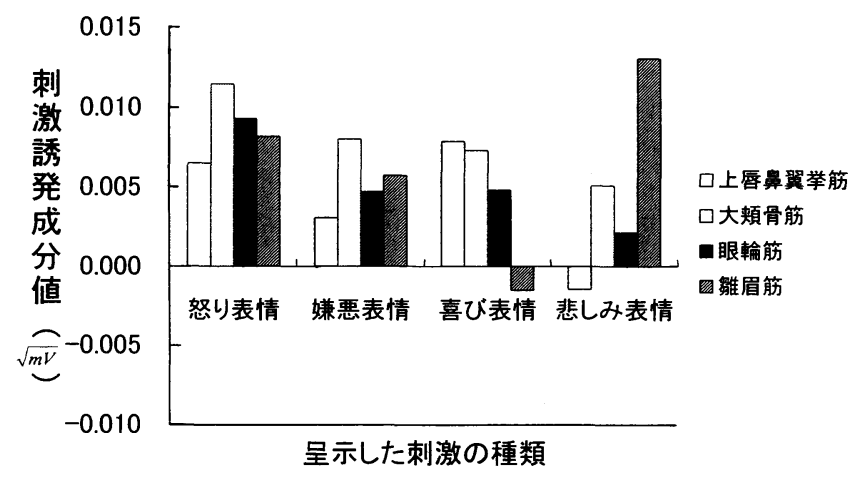

Figure 1. 各表情刺激に対する筋反応の平均（刺激呈示全期間 （15 秒間）のデータを使用）

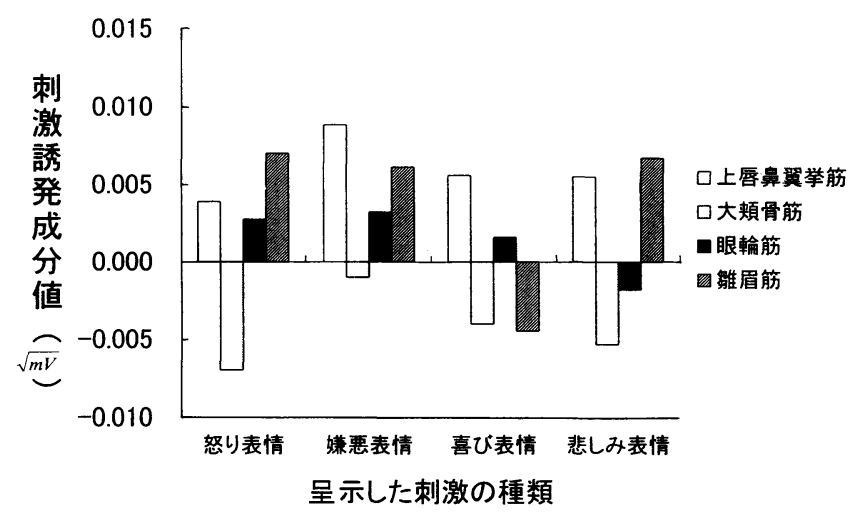

Figure 2. 各表情刺激に対する筋反応の平均（刺激提示後 1 秒間 のデータを使用) 
によって異なり得るという, 興味深い可能性を示して いる。

“表情模倣”と“情動伝染” の関係 本実験では, 表情刺激に対する筋反応だけでなく，それらを知覚し た後に生じる参加者の主観的な感情も測定している。 Hess \& Blairy（2001）をはじめとした先行研究では, “表情模倣” と“情動伝染” の関係が注目され，両者 の同時生起について議論が行われている。しかしなが ら, 先行研究では両者の関係について必ずしも明確な 実証デー夕は得られておらず, 改めて本実験のデー夕 を用いて “表情模倣”と“情動伝染”の同時生起につ いて，探索的な検討を行う。

Figure 3 は, 各感情表情が呈示された後の, 参加 者による主観的感情報告の平均を表している。

“喜び”表情を呈示した後の主観的感情に対し, 繰 り返しのある分散分析を行ったところ，主観的感情の 種類の効果が有意であり $(F(3,117)=21.73, p<$ $.01)$, 多重比較の結果, “喜び”感情とそれ以外の感 情の間に有意な差が確認された（喜びvs. 怒り： $t(39)=6.17, p<.01$; 喜び vs. 嫌悪 $: t(39)=2.96, p<$ .01 ; 喜びvs. 悲しみ $: t(39)=4.96, p<.01)$ 。

また “嫌悪”表情に対しても，参加者は有意に “嫌 悪”を強く感じていた。“嫌悪”表情に対する主観的 感情において, 感情の種類の効果は有意であり $(F(3,117)=59.28, p<.01)$, 多重比較においても “嫌悪” 感情とそれ以外の感情の間に有意な差が確認 された（嫌悪 vs. 怒り : $t(39)=6.22, p<.01$; 嫌悪 vs. 喜び： $t(39)=11.21, p<.01$; 嫌悪 vs. 悲しみ： $t(39)=8.41, p<.01)$ 。

これらの結果は, “喜び”あるいは “嫌悪”表情の 模倣に，それぞれ，“喜び”感情と “嫌悪” 感情の伝 染が伴う可能性を示している。

一方, “怒り”と“悲しみ”の両表情に対して最も 強く感じられていた感情は, それぞれ“怒り”感情も しくは“悲しみ” 感情ではなく,これら 2 種類の感情 に関しては, 表情模倣に情動伝染が伴ったとはいえな い。
以上の点をさらに詳しく検討するため, 参加者の顔 面筋反応と主観的感情報告の相関分析を行った。主観 的感情報告の妥当性には制約があるが (Nisbett \& Wilson, 1977)，ここでは経験的なデータの蓄積を目 的に，探索的な検討を行った。

Table 2 は刺激呈示全期間（15 秒間）の EMG デー 夕, Table 3 は刺激呈示直後 1 秒間の EMG デー夕を 用いた相関である。Table 2 から分かるように，“喜 び” 表情に対して“喜び”感情を強く報告するほど, 参加者は, “喜び” 表情で使用される大煩骨筋 $(\boldsymbol{r}=$ $0.384, p<.02)$ と眼輪筋 $(r=0.275, p<.09)$ を強く 活動させている。

一方，刺激呈示直後 1 秒間の EMG データとの相関 を示したTable 3 から, “怒り” 表情, “悲しみ”表情 に対する参加者の蛁眉筋の活動は, “怒り”感情を強 く報告するほど $(r=0.303, p<.07) ，$ た“悲しみ” 感情を強く報告するほど $(r=0.275, p<.10)$ ，それぞ れ大きくなっていることが分かる。

以上の結果は，刺激呈示全期間（15 秒間）の EMG データでは“喜び”において，また刺激呈示直後 1 秒 間の EMG データでは，“怒り”と“悲しみ”におい て，表情模倣と情動伝染が同時に生起した可能性を示 す。しかしながら両者の関係については，主観的感情 報告ではなく, 感情の生起をより直接的に示す指標を 用いて,さらに検討を進める必要がある。

\section{考 察}

本研究では，市川・牧野（2004）の印象評定法によ る検討を，顔面筋電図（facial EMG）という，より 客観的な測定法を用いて拡張した。この検討を通じ て, “怒り”，“嫌悪”，“喜び”，“悲しみ”の 4 感情に 関する表情模倣が，日本人サンプルにおいても存在す ることを明確に示すことができた。こうしたデータ は, 従来, 北米・ヨーロッパのみで検討されていた表 情模倣現象が，人の基本的・一般的性質である可能性 を強く示唆する知見である。

さらに本研究では, 表情模倣反応がピークに達する

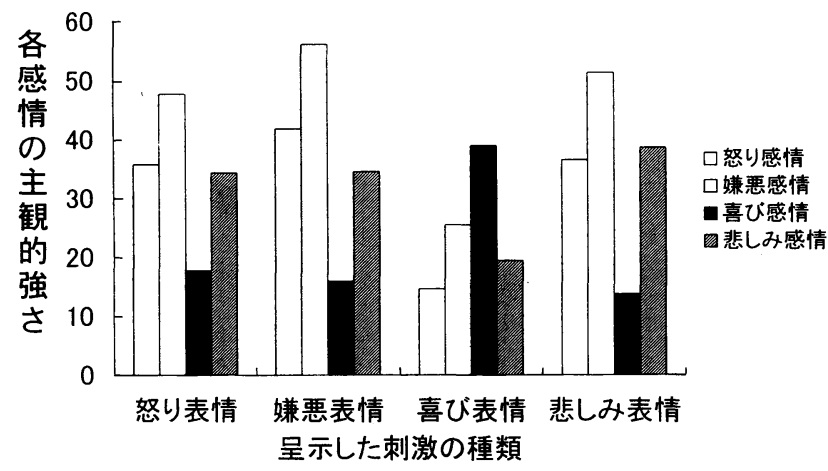

Figure 3. 各表情刺激に対する主観的感情報告の平均 
Table 2

刺激呈示全期間（15 秒間）における筋電位と主観的感情報告の相関

\begin{tabular}{lccccc}
\hline & $\begin{array}{c}\text { 怒り表情 } \\
\text { に対する } \\
\text { 㱀眉筋 }\end{array}$ & $\begin{array}{c}\text { 嫌悪表情 } \\
\text { に対する } \\
\text { 上唇鼻翼挙筋 }\end{array}$ & $\begin{array}{c}\text { 喜び表情 } \\
\text { に対する } \\
\text { 大煩骨筋 }\end{array}$ & $\begin{array}{c}\text { 喜び表情 } \\
\text { に対する } \\
\text { 眼輪筋 }\end{array}$ & $\begin{array}{c}\text { 悲しみ表情 } \\
\text { に対する } \\
\text { 㱀眉筋 }\end{array}$ \\
\hline 怒り表情への怒り感情 & -.027 & - & - & - & - \\
嫌悪表情への嫌悪感情 & - & -.102 & - & - & - \\
喜び表情への喜び感情 & - & - & $-384^{*}$ & $.275^{+}$ & - \\
悲しみ表情への悲しみ感情 & - & - & - & - & -.062 \\
\hline
\end{tabular}

${ }^{*} p<.05, \quad-p<.10$

Table 3

刺激呈示直後 1 秒間における筋電位と主観的感情報告の相関

\begin{tabular}{|c|c|c|c|c|c|}
\hline & $\begin{array}{l}\text { 怒り表情 } \\
\text { に対する } \\
\text { 蚾眉筋 }\end{array}$ & $\begin{array}{c}\text { 嫌悪表情 } \\
\text { に対する } \\
\text { 上唇鼻翼挙筋 }\end{array}$ & $\begin{array}{l}\text { 喜び表情 } \\
\text { に対する } \\
\text { 大煩骨筋 }\end{array}$ & $\begin{array}{c}\text { 喜び表情 } \\
\text { に対する } \\
\text { 眼輪筋 }\end{array}$ & $\begin{array}{c}\text { 悲しみ表情 } \\
\text { に対する } \\
\text { 㱀眉筋 }\end{array}$ \\
\hline 怒り表情への怒り感情 & $.303^{+}$ & - & - & - & - \\
\hline 嫌悪表情への嫌悪感情 & - & .169 & - & - & - \\
\hline 喜び表情への喜び感情 & - & - & .123 & .081 & - \\
\hline 悲しみ表情への悲しみ感情 & - & - & - & - & $.275^{+}$ \\
\hline
\end{tabular}

時間が，感情の種類によって異なるという興味深い知 見が得られた。具体的には，“怒り”及び“喜び”表 情の模倣反応のピークはゆっくり生じたが，“嫌悪” 表情の模倣反応のピークは，“怒り”及び“喜び”と 比較して早く表れた。一方“悲しみ”表情の模倣反応 は，刺激呈示期間中，常に高いレベルで保たれていた と考えられる。各顔面筋の生理的特性も考えられる が，今後はなぜこのような模倣の時間差が生じたのか について, 理論的な検討を進めていく必要がある。例 えば, Kameda \& Tamura（in press）は，恐怖表情の 模倣に関係すると考えられる“個体間での警戒行動の 拡散”が，集団が共有する危険の早期発見に，有効に 働き得る可能性を実証的に示している。本研究では恐 怖表情については扱わなかったが，それぞれの表情模 倣がどのようなメリットを個体にもたらすのかという 問題を検討することは，表情模倣のメカ二ズムを適応 的視点 (Hastie \& Kameda, 2005; Kameda \& Hastie, 2004）から明らかにするうえで重要だろう。

さらに，本研究から，表情模倣が情動伝染現象と関 係する可能性が部分的に示された。Hess \& Blairy （2001）は，他者との感情の共有が表情模倣を通じて 行われているのではないかと議論している。両者の関 係に関する先行研究の結果は必ずしも明確ではなく, 本研究の結果もまた，示唆的であるにすぎない。しか し，両者の関係は“共感”の生起メカニズムについて 重要な理論的含意をもち，今後の有望な検討テーマで
ある。

一方本実験には，未だ数多くの技術的問題が残され ている。本実験では刺激として静止画像を用いたが, 静止した他者表情を知覚するという状況は，現実場面 としては考えにくい。ゆえに，本来生じ得るはずの顔 面筋の反忘が，はっきりと表れていない可能性が考え られる。またあまり日常的ではない誇張した表情刺激 に対して，“笑い”が生じた可能性も考えられる。“怒 り”表情に対する眼輪笳と大煩骨筋，また“嫌悪”表 情に対する大煩骨筋の活性化は，このような原因で生 じたのかもしれない。なお，大煩骨筋は “嫌悪”表情 の表出で用いられる上唇鼻翼挙筋に位置的に近く, “嫌悪”表情に対する大煩骨筋の反応は，上唇鼻翼挙 筋の活性化に影響を受けた可能性も大きい。いずれに せよ，今後は，刺激としてビデオ画像もしくはモーフ イング技術により作成した動画を用いるなど，より現 実場面に即した形での実験が望まれる。

また本実験は，連続して呈示される刺激写真を見続 け，各刺激写真に対する主観的感情を回答するとい う，非常に単純な実験手続きを用いているが，この手 法では, 参加者の覚醒水準の維持が大きな問題とな る。上記の刺激に関する問題と並行して, 参加者の覚 醒水準をいかに維持するかという問題についても, 改 善の必要があるといえよう。 


\section{引用文献}

Blairy, S., Herrera, P., \& Hess, U. (1999). Mimicry and the judgment of emotional facial expressions. Journal of Nonverbal Behavior, 23, 5-41.

Cacioppo, J. T., Martzke, J.S., Petty, R. E., \& Tassinary, L. G. (1988). Specific forms of facial EMG response index emotions during an interview: From Darwin to the continuous flow hypothesis of affect-laden information processing. Journal of Personality and Social psychology, 54, 592-604.

Dimberg, U. (1982). Facial reaction to facial expression. Psychophysiology, 19, 643-647.

Dimberg, U., \& Thunberg, M. (1998). Rapid facial reactions to emotional facial expressions. Scandinavian Journal of Psychology, 39, 39-45.

Dimberg, U., Thunberg, M., \& Elmehed, K. (2000). Unconscious facial reactions to emotional facial expressions. Psychological Science, 11, 86-89.

Fridlund, A. J., \& Cacioppo, J. T. (1986). Guidelines for human electromyographic research. Psychophysiology, 23, 567-589.

Gump, B. B., \& Kulik, J. A. (1997). Stress, affiliation, and emotional contagion. Journal of Personality and Social Psychology, 72, 305-319.

Hastie, R., \& Kameda, T. (2005). The robust beauty of majority rules in group decisions. Psychological Review, 112, 494-508.

Hatfield, E., Cacioppo, J. T., \& Rapson, R. (1994). Emotional contagion. New York: Cambridge University Press.

Hess, U., \& Blairy, S. (2001). Facial mimicry and emotional contagion to dynamic emotional facial expressions and their influence on decoding accuracy. International Journal of Psychophysiology, 40, 129-141.

Hinsz, V. B., \& Tomhave, J. (1991). Smile and (half) the world similes with you, frown and you frown alone. Personality and Social Psychology Bulletin, 17, 586-592.

市川寛子・牧野順四郎（2004）。刺激表情に対する観 察者の同調的表情 心理学研究, 75, 142-147.

(Ichikawa, H., \& Makino, J. (2004). Concordance of facial reactions to facial expressions. Japanese Journal of Psychology, 75, 142-147.)

Kameda, T., \& Hastie, R. (2004). Building an even better conceptual foundation. Behavioral and Brain Sciences, 27, 345-346.

Kameda, T., \& Tamura, R. (in press). "To eat or not to be eaten ?" Collective risk-monitoring in groups. Journal of Experimental Social Psychology.

Lundqvist, L. O., \& Dimberg, U. (1995). Facial expression are contagious. International Journal of Psychophysiology, 9, 203-211.

Matsumoto, D., \& Ekman, P. (1988). Japanese and Caucasian Facial Expressions of Emotion (JACFEE) and Neutral Faces (JACNeuF) $[\mathrm{CD}]$. San Francisco, CA: Human Interaction Laboratory, University of California.

Nisbett, R. E., \& Wilson, T. D. (1977). Telling more than we can know: Verbal reports on mental processes. Psychological Review, 84, 231-259.

-2004.11.10 受稿, 2006. 5.7 受理—— 